\title{
OPEN ACCESS \\ Gene expression analyses of hepatocellular adenoma and hepatocellular carcinoma from the marine flatfish Limanda limanda
}

\author{
Hamish J. Small ${ }^{1,4}$, Timothy D. Williams ${ }^{2}$, Joachim Sturve ${ }^{3}$, James K. Chipman ${ }^{2}$, \\ Andrew D. Southam ${ }^{2}$, Tim P. Bean ${ }^{1}$, Brett P. Lyons ${ }^{1}$, Grant D. Stentiford ${ }^{1, *}$ \\ ${ }^{1}$ Centre for Environment, Fisheries and Aquaculture Science (Cefas), Barrack Road, Weymouth, Dorset DT4 8UB, UK \\ ${ }^{2}$ School of Biosciences, University of Birmingham, Edgbaston, Birmingham B15 2TT, UK \\ ${ }^{3}$ Department of Zoophysiology, Göteborg University, Box 463, 40530, Göteborg, Sweden
}

${ }^{4}$ Present address: Virginia Institute of Marine Science (VIMS), College of William and Mary, Gloucester Point, Virginia, USA

\begin{abstract}
At selected sites around the UK, the offshore sentinel flatfish species dab Limanda limanda are found to contain elevated levels of macroscopic liver tumors. Previous proteomic and metabolomic studies have demonstrated that differences exist between tumor and non-tumor tissues; however, these differing features were not identified, and little is known about the changes at the gene expression level, or whether prognostic markers are present and can be identified. A flounder Platichthys flesus custom cDNA microarray and RT-PCR were used to investigate hepatic mRNA expression in the histologically confirmed tumors, hepatocellular adenoma (HA) and hepatocellular carcinoma (HC) from dab, and in adjacent normal tissue from the same fish. Differences in gene expression were observed between tumor and normal tissues, and between tumor types. A class-prediction approach using 50 transcripts revealed sufficient group-specific expression profiles to allow segregation of samples dependent on their tumor type or the sex of the host. Vitellogenins were found to display the greatest induction (up to 500-fold induction) in some $\mathrm{HC}$ tumors from female fish and in both HA and HC tumors from males. To the best of our knowledge, this is the first report of the association of vitellogenin expression with tumors of wild fish.
\end{abstract}

KEY WORDS: Cancer - Dab · Genomics - Limanda limanda - Liver · Tumor · Vitellogenins · Marine environment · Monitoring

Resale or republication not permitted without written consent of the publisher

\section{INTRODUCTION}

Fish have a long history of use in environmental carcinogenesis research and have served as valuable alternatives to conventional rodent models and to samples collected from human tumors. They have well described tumor pathologies, are sensitive to many classes of carcinogens, are responsive to many tumor promoters and inhibitors, and develop neoplasms that are histologically similar to human cancers (Bailey et al. 1996, Stern \& Zon 2003). In the marine sentinel species dab Limanda limanda, liver lesions recorded have been histopathologically assigned to 5 main categories: non-specific inflammatory responses, non-neo- plastic toxicopathic lesions, foci of cellular alteration, benign tumors, and malignant tumors (Feist et al. 2004). Additional sub-typing results in the classification of approximately 30 categories of liver lesions under the Biological Effects Quality Assurance in Monitoring (BEQUALM) program (Feist et al. 2004). The detection of liver lesions has been incorporated into several national and international monitoring programs (Meyers et al. 1990, Vethaak \& Wester 1996, Lang 2002, Lyons et al. 2004, Stentiford et al. 2009, Vethaak et al. 2009) and serves as a reliable and sensitive indicator of the health status of fish populations and, as such, the health of the environment (Thain et al. 2008). Furthermore, the use of dab as a model 
species may lead to a better understanding of the environmental factors involved in the formation of cancer, particularly since patterns of occurrence in wild fish are consistent between distinct sites and years (Stentiford et al. 2009). Using the BEQUALM classification scheme for liver histopathology, specific sample groups can be identified (e.g. 'no liver pathology observed', 'pre-neoplastic lesions', 'benign tumor', 'malignant tumor') and used to phenotypically 'anchor' samples for further bioinformatic approaches (Stentiford et al. 2005).

Little research has been conducted to investigate gene expression profiles in naturally occurring tumors of wild fish. The expression changes that are likely to occur in and between tumor sub-types may well provide the foundation for molecular classification of tumors, and provide prognostic markers that can be used as indicators of pollution-induced damage. In addition, utilization of tumor tissues from wild animals will provide additional useful information for comparison with laboratory-induced tumors, since this will likely reflect the multi-factorial nature of cancer formation in natural populations (du Corbier et al. 2005, Stentiford et al. 2005, Ward et al. 2006). DNA microarrays have been applied in many areas of biological research, including human cancer (Rhodes et al. 2004), and are increasingly being used in studies of gene expression in fish (Douglas 2006), primarily as a tool for understanding development processes and basic physiology. Recently, a custom cDNA microarray for the European flounder Platichthys flesus was used to detect toxic stress responses in fish from polluted estuaries (Williams et al. 2003), oxidative stress and other responses in fish exposed to cadmium (Sheader et al. 2006, Williams et al. 2006), and gene expression in response to 17- $\beta$ estradiol (Williams et al. 2007). These studies demonstrate the applicability of microarray technologies and real-time RT-PCR for investigating and understanding the transcriptional responses of environmentally important sentinel fish species.

Recent pilot studies from our group, which combined the use of histopathology, proteomics and metabalomics, identified specific protein and metabolite profiles in liver tumors from dab (Stentiford et al. 2005). Subsequent studies by Ward et al. (2006) reported that proteomic analysis of dab plasma samples could also indicate the presence or absence of liver tumors and the geographic origin of the host. We report here a proofof-concept study in which we have investigated the transcriptional profiles of liver tumors from dab, and whether transcriptional differences exist between 2 different tumor types. Histopathologically confirmed specimens were selected to create sample groups of hepatocellular adenoma (HA) and hepatocellular carcinoma (HC) and sex of fish (male or female). Infor- mation relating to the geographical origin of the samples, sex, tumor type and secondary lesions/pathologies was also recorded. Transcriptional responses were measured using a custom cDNA microarray and RTPCR primers developed for European flounder (Williams et al. 2003). Data are discussed in relation to transcript expression profiles and the combined use of histopathological and molecular techniques in environmental carcinogenesis research.

\section{MATERIALS AND METHODS}

Sample collection. Dab were captured at Clean Seas Environmental Monitoring Programme (CSEMP) sites in the UK during June and July of 2007 using a standard Granton trawl of approximately 30 min duration. Sampling is undertaken at this time to miss the main spawning season for dab, which around the British Isles falls between April and May (Rijnsdorp et al. 1992, Fox et al. 1997). Therefore, while the fish used in this study are all sexually mature, they have been sampled outside their breeding season. Upon landing, we immediately placed the fish in flow-through holding tanks containing aerated seawater. The fish were then measured, sexed (Table 1) and examined for indicators of external diseases according to standard procedures (Bucke et al. 1996, Anonymous 2004). Fish were then sacrificed by a blow to the head followed by immediate severing of the spinal cord. In selected fish where sizeable visible liver nodules were present, the liver was removed from the fish and a small section (approx. 2 to $3 \mathrm{~mm}^{3}$ ) of the tumor and adjacent non-tumor tissue were excised and immediately frozen in liquid nitrogen, and later stored at $-80^{\circ} \mathrm{C}$. In addition, a section was made through the same liver so as to obtain both tumor and non-tumor tissues according to the methods of Feist et al. (2004). The section was fixed in $10 \%$ neutral buffered formalin (NBF) for $24 \mathrm{~h}$, and then transferred to $70 \%$ industrial methylated spirit (IMS) for subsequent histological confirmation of the lesion type.

Histopathology. Fixed liver samples were processed to wax in a vacuum infiltration processor using standard procedures (Feist et al. 2004, Stentiford et al. 2009). Sections were cut at 3 to $5 \mu \mathrm{m}$ on a rotary microtome and the resulting sections mounted onto glass slides before staining with hematoxylin and eosin (H\&E) according to standard procedures (Feist et al. 2004). Histological confirmation of lesion types was carried out using guidelines set out in the BEQUALM program (Feist et al. 2004). Lesions relevant to the current study include the benign neoplasm HA and the malignant neoplasm HC.

Expression analysis by cDNA microarray. The genomic tool for bio-monitoring of pollutant coastal 
Table 1. Limanda limanda. Sample information and lesion categories. HC: hepatocellular carcinoma; HA: hepatocellular adenoma; bFCA: basophilic focus of cellular alteration; eFCA: eoisonophilic focus of cellular alteration; vFCA: vacuolated focus of cellular alteration; CN: coagulative necrosis; MMA: melanomacrophage aggregates; LMI: lymphocytic/monocytic infiltration; Re: regeneration; Li: lipoidosis; Fi: fibrosis; Pl: Phospholipidosis; FI: fibrilar inclusions; HNP: Hepatocellular and nuclear pleomorphism; Cefas: Centre for Environment, Fisheries and Aquaculture Science; Y: yes; N: no

\begin{tabular}{|c|c|c|c|c|c|c|c|c|}
\hline $\begin{array}{l}\text { Fish } \\
\text { ID }\end{array}$ & $\begin{array}{l}\text { Cefas } \\
\text { reference }\end{array}$ & Sample site & Sex & $\begin{array}{l}\text { Fish size } \\
\quad(\mathrm{cm})\end{array}$ & $\begin{array}{l}\text { Principal } \\
\text { lesion }\end{array}$ & $\begin{array}{l}\text { Associated secondary } \\
\text { lesions/pathology }\end{array}$ & $\begin{array}{l}\text { Microarray } \\
\text { analysis }\end{array}$ & $\begin{array}{l}\text { RT-PCR } \\
\text { analysis }\end{array}$ \\
\hline 1 & RA07046-60 & West Dogger & $\mathrm{F}$ & 21 & HA & $\mathrm{CN}, \mathrm{MMA}, \mathrm{LMI}$ & $\mathrm{Y}$ & $\mathrm{Y}$ \\
\hline 2 & RA07046-64 & West Dogger & $\mathrm{F}$ & 26 & HA & Pl, FI, MMA, Re & $\mathrm{Y}$ & $\mathrm{Y}$ \\
\hline 3 & RA07046-65 & West Dogger & $\mathrm{F}$ & 25 & HA & CN, MMA, LMI & $\mathrm{Y}$ & $\mathrm{Y}$ \\
\hline 4 & RA07045-1200 & North Dogger & $\mathrm{F}$ & 23 & $\mathrm{HC}$ & eFCA, MMA, LMI, Re & $\mathrm{N}$ & $\mathrm{Y}$ \\
\hline 5 & RA07046-36 & Off Humber & $\mathrm{F}$ & 22 & $\mathrm{HC}$ & vFCA, MMA, LMI & $\mathrm{Y}$ & $\mathrm{Y}$ \\
\hline 6 & RA07046-62 & West Dogger & $\mathrm{F}$ & 27 & $\mathrm{HC}$ & $\mathrm{HA}, \mathrm{bFCA}, \mathrm{CN}, \mathrm{Li}, \mathrm{MMA}$ & $\mathrm{Y}$ & $\mathrm{Y}$ \\
\hline 7 & RA07045-470 & SE Isle of Man & M & 20 & HA & $\mathrm{CN}, \mathrm{MMA}$ & $\mathrm{Y}$ & $\mathrm{Y}$ \\
\hline 8 & RA07046-38 & Off Humber & M & 22 & HA & MMA & $\mathrm{Y}$ & $\mathrm{Y}$ \\
\hline 9 & RA07046-66 & Amble & M & 20 & HA & MMA & $\mathrm{Y}$ & $\mathrm{Y}$ \\
\hline 10 & RA07045-111 & Red Wharf Bay & M & 20 & $\mathrm{HC}$ & HNP & $\mathrm{Y}$ & $\mathrm{Y}$ \\
\hline 11 & RA07046-52 & Central Dogger & M & 23 & $\mathrm{HC}$ & vFCA, eFCA, bFCA, MMA, Re & $\mathrm{Y}$ & $\mathrm{Y}$ \\
\hline 12 & RA07046-59 & West Dogger & M & 20 & $\mathrm{HC}$ & MMA, LMI & $\mathrm{Y}$ & $\mathrm{Y}$ \\
\hline
\end{tabular}

impact (GENIPOL) cDNA microarray for European flounder was employed to determine mRNA expression differences between tumor and non-tumor liver samples from dab, and has been described previously (Williams et al. 2003, 2006, 2007, Diab et al. 2007). We have used this array to investigate cross-species hybridization efficiency in different flatfish species (plaice Pleuronectes platessa and sole Solea solea) (Cohen et al. 2007) and experimentally determined $79 \%$ intra-family hybridization efficiency (percentage of non-differentially, or up-regulated, transcripts). In addition, we have successfully employed the flounder array for transcriptomics in Senegalese sole $S$. senegalensis, a species that is considerably more evolutionarily distant from European flounder than the dab (Osuna-Jiménez et al. 2009).

RNA was extracted from the frozen tumor and nontumor samples using an RNeasy Mini Kit (Qiagen) and quantified using a NanoDrop-1000 (Thermo Fisher Scientific). In selected samples, RNA quality was assessed using an Experion Bioanalyzer (Bio-Rad). Microarray experiments were carried out as previously (Williams et al. 2003, 2006, 2007, Diab et al. 2008). Briefly, $20 \mu \mathrm{g}$ total RNA was treated to remove DNA contamination using a DNAfree kit (Ambion) and reverse transcribed using Oligo(dT) 12-18 primers (Alta Bioscience). cDNA (500 ng) was labeled with Cy5-dCTP or Cy3-dCTP (Amersham). Cy5-labeled dab tumor cDNA (60 pmol incorporated) was mixed with Cy3-labeled dab non-tumor cDNA (60 pmol incorporated). Each of the 12 hybridizations consisted of tumor cDNA and non-tumor cDNA from 1 individual fish. These were hybridized, washed and scanned (Axon 4000B; Molecular Devices). Data were captured using Genepix software (Molecular Devices).
The Genespring v7.2 software package (Agilent) was used to analyze microarray data. Clones corresponding to the same gene were considered as replicate spots. After Lowess normalization, low-trust spots were discarded. Lists of apparently differentially expressed genes were generated by finding genes that differed by more than 1.5-fold in expression in samples grouped by sex and tissue-type parameters. Statistically significant differences were determined using a parametric Welch t-test. The p-value cut-off was 0.05, and a Benjamini and Hochberg (Benjamini \& Hochberg 1995) multiple testing correction was used, for a false discovery rate (FDR) cut-off of 0.05. For class-prediction, the K-nearest neighbour approach was employed with gene selection by Golub's method (Golub et al. 1999) incorporated within the Genespring software package. The output of this was 50 genes the expression of which was most closely associated with membership of the designated sample groups. Principal component analysis and clustering were carried out within Genespring; clustering employed a Spearman algorithm. Heat maps were generated using Genespring. Gene expression values (tumor/'normal') were compared between samples grouped by other parameters (sampling site, sex, length and secondary pathologies shown in Table 1) by t-test with a Benjamini and Hochberg multiple testing correction for FDR $<0.05$.

Expression analysis by real-time RT-PCR. Selected transcripts (e.g. vitellogenins) were assayed by quantitative real-time RT-PCR to confirm the significance of the array results, and also to investigate other genes suggested to have biological significance in tumor formation or progression for which sequence information or primers were available (e.g. thioredoxin [THX] and glutathione-S-transferase [GST]). Total RNA was 
again extracted from frozen liver tumor and non-tumor samples (see Table 1) using an RNeasy Mini Kit, as described above. cDNA was synthesized using a QuantiTect Reverse Transcription Kit (Qiagen). A 1:10 dilution of the synthesized cDNAs was used in all subsequent real time PCR reactions. Primers previously designed for several genes from the closely related flatfish, the European flounder (Williams et al. 2003, Sheader et al. 2006) were used to measure vitellogenin-B (VTG), THX, GST, and 2 commonly used normalization genes, 18S rRNA (18S) and $\alpha$-tubulin (ATUB). Samples were assayed in duplicate on a StepOne Real-Time thermocycler (Applied Biosystems). Each $20 \mu \mathrm{l}$ PCR reaction contained the following: $10 \mu \mathrm{l}$ Power SYBR-Green $2 \times$ PCR Master Mix (Qiagen), $400 \mathrm{nM}$ of each primer, and $2 \mu \mathrm{l}$ of a 1:10 dilution of cDNA. Thermocycling conditions consisted of an initial denaturation temperature of $95^{\circ} \mathrm{C}$ for $10 \mathrm{~min}$, followed by 40 cycles at $95^{\circ} \mathrm{C}$ for $15 \mathrm{~s}, 52^{\circ} \mathrm{C}$ for $20 \mathrm{~s}$, and $72^{\circ} \mathrm{C}$ for $20 \mathrm{~s}$. Following amplification, a dissociation profile $\left(95^{\circ} \mathrm{C}\right.$ for $15 \mathrm{~s}, 52^{\circ} \mathrm{C}$ for $1 \mathrm{~min},+0.3^{\circ} \mathrm{C}$ $\mathrm{min}^{-1}$ increasing to $95^{\circ} \mathrm{C}$ for $15 \mathrm{~s}$ ) was added to generate a melt-curve thermal profile to examine the amplification products. Reaction conditions and reagent concentrations were the same for the 5 primer pairs used. Threshold cycle $\left(C_{t}\right)$ values obtained for $18 \mathrm{~S}$ and ATUB transcripts from HA, $\mathrm{HC}$ and matching normal tissues, were compared to identify a suitable internal control for quantification. Relative quantification (Livak \& Schmittgen 2001) was employed to analyze the RT-PCR data. Means $( \pm$ SD) were calculated for each duplicate sample for both tumor and normal hepatic tissues, and then pooled to obtain relative expression data for each tumor type.

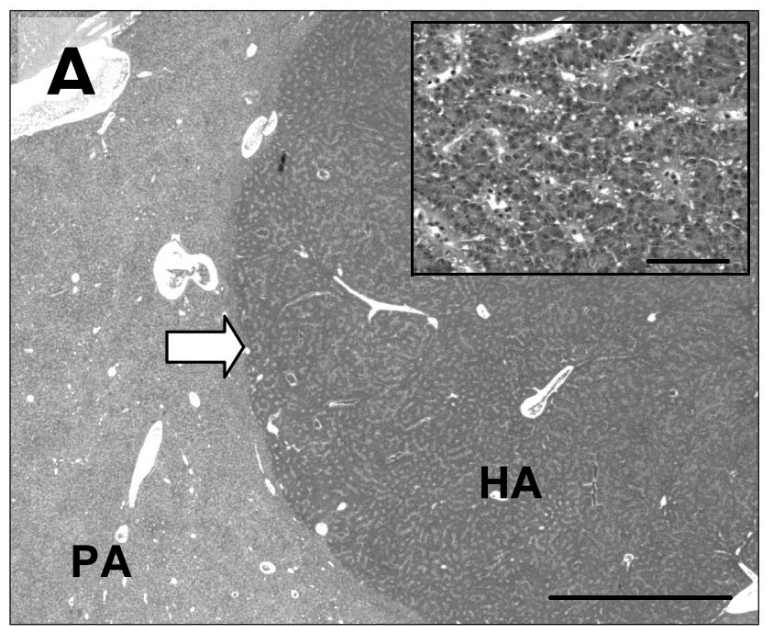

To further confirm the amplification of the correct target, each RT-PCR product from 2 select dab VTG/GST/THX and ATUB amplifications were purified with the Wizard SV gel and PCR Clean-Up System (Promega). Amplicons were sequenced using a BigDye Terminator v3.1 Cycle Sequencing Kit (Applied Biosystems) and products electrophoresed on an ABI PRISM 3100-Avant genetic analyser (Applied Biosystems) following standard procedures. Consensus sequences were constructed from the 2 sequencing reactions using Vector NTI Advance v10.3.0 software (Invitrogen) and the resulting sequences compared to the European flounder sequences in GenBank using the Basic Local Alignment Search Tool (BLAST) (Altschul et al. 1990).

\section{RESULTS}

\section{Liver histopathology}

Grossly visible liver nodules (principal lesion) were observed as masses of $\geq 2 \mathrm{~mm}$ in diameter on the upper and lower surface of the dissected liver. Liver lesions in resected dab samples were characterized as either HA or HC according to the diagnostic criteria set out in the BEQUALM program (Feist et al. 2004). HA were characterized by their distinctive border and compression of surrounding parenchyma, enlargement and increased number of blood vessels, thickened hepatocellular trabecular cords and a lack of nuclear and cellular atypia compared to the surrounding parenchyma (Fig. 1A). HC were characterized by a generally less distinctive border with the surround-

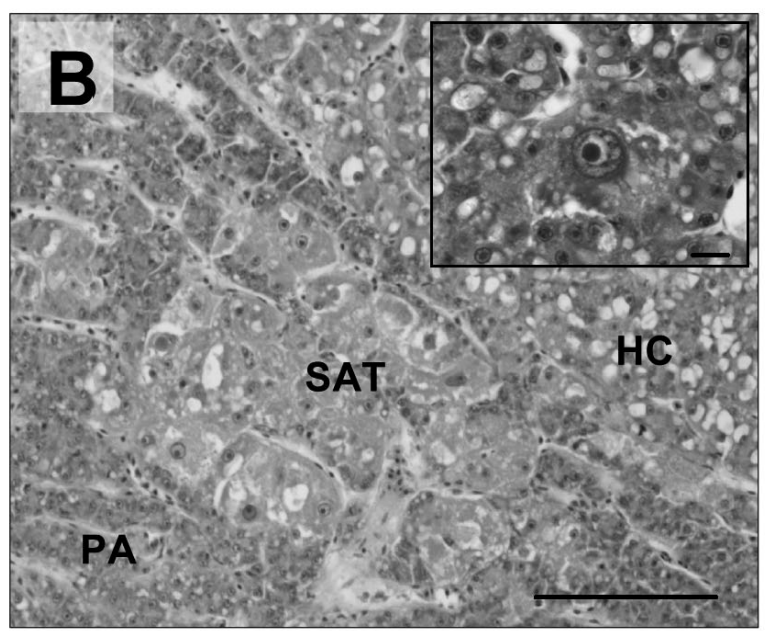

Fig. 1. Limanda limanda. Histopathology of liver neoplasia in dab. Discrimination of hepatocellular adenoma (HA) from hepatocellular carcinoma (HC). (A) HA with distinctive border (arrow) and compression of surrounding parenchyma $(\mathrm{PA})$. Scale bar $=$ $1 \mathrm{~mm}$. Inset: architectural alteration caused by enlargement and increased number of blood vessels and thickened hepatocellular trabecular cords. Scale bar $=100 \mu \mathrm{m}$. (B) HC with satellite lesion at periphery (SAT) and a less distinctive border with surrounding PA. Scale bar $=100 \mu \mathrm{m}$. Inset: Atypical hepatocyte with hypertrophic nucleus within HC. Scale bar $=10 \mu \mathrm{m}$ 
ing parenchyma, atypical hepatocytes with hypertrophic nuclei, and the presence of multinucleate hepatocytes (Fig. 1B). In all cases, other non-specific pathologies were recorded in the surrounding nontumor tissues (see Table 1).

\section{Microarray analysis of mRNA expression}

Data from the microarray experiments were grouped by sex and lesion type (HA or HC). Mean expression of each group of samples is shown in Tables $2 \& 3$ for those

Table 2. Limanda limanda. Transcripts significantly (false discovery rate, FDR < 0.05) induced at least 1.5 -fold (fold changes in gene expression between tumor and non-tumor) in one or more groups of tumor samples. This employed the K-nearest neighbors approach with gene selection by Golub's method. GenBank: example flounder GenBank accession number; Common name: putative identity of gene. Those samples with FDR $<0.05$ are shown in bold italics; those with single $t$-test $\mathrm{p}$-values $<0.05$ are shown in bold. F-HA: female hepatocellular adenoma; F-HC: female hepatocellular carcinoma; M-HA: male hepatocellular adenoma; M-HC: male hepatocellular carcinoma

\begin{tabular}{|c|c|c|c|c|c|}
\hline GenBank & Common name & F-HA & $\mathrm{F}-\mathrm{HC}$ & M-HA & $\mathrm{M}-\mathrm{HC}$ \\
\hline DV570392 & 60S ribosomal protein L10 & 1.62 & 2.20 & 1.64 & 1.57 \\
\hline DV567581 & $3 \beta$ beta-hydroxysteroid dehydrogenase type VII & 1.53 & 2.05 & 1.65 & 1.51 \\
\hline DV565518 & $40 \mathrm{~S}$ ribosomal protein $\mathrm{S} 12$ & 1.32 & 2.19 & 1.57 & 1.42 \\
\hline DV565793 & 60S acidic ribosomal protein P0 (L10E) & 1.23 & 1.88 & 1.63 & 1.44 \\
\hline AJ605265 & 60S ribosomal protein L36a & 1.31 & 1.88 & 1.53 & 1.39 \\
\hline DV566503 & 60S ribosomal protein L18 & 1.32 & 1.88 & 1.51 & 1.34 \\
\hline AJ605263 & 60S ribosomal protein L3 & 1.38 & 1.84 & 1.39 & 1.42 \\
\hline DV566031 & 40S ribosomal protein S20 & 1.14 & 2.10 & 1.52 & 1.26 \\
\hline DV568038 & 60S ribosomal protein $\mathrm{L7a}$ & 1.23 & 1.86 & 1.58 & 1.35 \\
\hline DV570097 & SSR alpha subunit & 1.14 & 2.28 & 1.24 & 1.35 \\
\hline AJ605290 & 40S ribosomal protein $\mathrm{S} 7$ & 1.21 & 1.93 & 1.47 & 1.39 \\
\hline DV565339 & 40S ribosomal protein $\mathrm{S} 11$ & 1.09 & 1.91 & 1.61 & 1.35 \\
\hline DV565525 & 40S ribosomal protein S16 & 1.25 & 1.89 & 1.47 & 1.34 \\
\hline DV565753 & 40S ribosomal protein $\mathrm{S} 25$ & 1.33 & 1.97 & 1.42 & 1.23 \\
\hline DV568176 & cDNA clone sim to selenoprotein $\mathrm{P}$, plasma, 1a & 1.22 & 2.68 & 0.92 & 1.11 \\
\hline AJ578009 & 60S Ribosomal protein L35 & 1.25 & 1.79 & 1.52 & 1.34 \\
\hline DV566652 & 40S ribosomal protein S19 & 1.17 & 1.83 & 1.57 & 1.31 \\
\hline DV565724 & 60S ribosomal protein L15 & 1.18 & 1.80 & 1.61 & 1.27 \\
\hline DV565343 & 60S ribosomal protein L29 & 1.30 & 1.85 & 1.47 & 1.23 \\
\hline AJ305219 & 40S ribosomal protein S8 & 1.15 & 1.81 & 1.54 & 1.34 \\
\hline DV568255 & $40 \mathrm{~S}$ ribosomal protein $\mathrm{S} 27 \mathrm{a}$ & 1.21 & 1.86 & 1.51 & 1.25 \\
\hline DV565726 & 40S ribosomal protein S5 & 1.25 & 1.71 & 1.45 & 1.42 \\
\hline AJ310439 & 40S ribosomal protein S26 & 1.28 & 1.88 & 1.44 & 1.22 \\
\hline DV565683 & 60 S ribosomal protein L11 & 1.25 & 1.77 & 1.48 & 1.30 \\
\hline DV565605 & $40 \mathrm{~S}$ ribosomal protein $\mathrm{S} 17$ & 1.26 & 1.87 & 1.42 & 1.21 \\
\hline DV567339 & MAP kinase-interacting serine/threonine kinase 2 & 1.04 & 1.30 & 1.67 & 1.73 \\
\hline DV565775 & 60S ribosomal pProtein L9 & 1.15 & 1.89 & 1.47 & 1.22 \\
\hline AJ300776 & Eukaryotic translation elongation factor 2 & 1.11 & 1.70 & 1.50 & 1.39 \\
\hline DV565606 & $60 \mathrm{~S}$ ribosomal protein L41 & 1.16 & 1.71 & 1.53 & 1.30 \\
\hline DV566097 & Ubiquitin-like FUBI/ S30 ribosomal fusion protein & 1.20 & 1.84 & 1.42 & 1.21 \\
\hline DV565723 & 40S ribosomal protein $\mathrm{S} 28$ & 1.23 & 1.59 & 1.43 & 1.37 \\
\hline AJ305223 & 60S ribosomal protein L27a (L22) & 1.09 & 1.80 & 1.42 & 1.25 \\
\hline DV565446 & 40S ribosomal protein $\mathrm{S} 18$ & 1.18 & 1.66 & 1.39 & 1.32 \\
\hline DV565839 & 60 S ribosomal protein L17 & 1.18 & 1.68 & 1.44 & 1.23 \\
\hline DV566429 & 40S ribosomal protein $\mathrm{S} 21$ & 1.15 & 1.86 & 1.32 & 1.21 \\
\hline DV565305 & $60 \mathrm{~S}$ ribosomal protein L13A & 1.24 & 1.69 & 1.28 & 1.29 \\
\hline DV565555 & 60S ribosomal protein L28 & 1.08 & 1.72 & 1.47 & 1.24 \\
\hline AJ606078 & 60S ribosomal protein L10a & 1.12 & 1.72 & 1.39 & 1.25 \\
\hline DV565296 & 60S ribosomal protein L22 & 1.10 & 1.82 & 1.32 & 1.23 \\
\hline DV565427 & 60S ribosomal protein $\mathrm{L} 37 \mathrm{a}$ & 1.30 & 1.63 & 1.27 & 1.26 \\
\hline DV565885 & $60 \mathrm{~S}$ acidic ribosomal protein $\mathrm{P} 1$ & 1.26 & 1.74 & 1.33 & 1.13 \\
\hline DV565344 & 40S ribosomal protein $\mathrm{S} 27$; metallopanstimulin 1 & 1.10 & 1.67 & 1.35 & 1.26 \\
\hline DV566231 & 40 S ribosomal protein $\mathrm{S} 23$ & 1.25 & 1.62 & 1.31 & 1.17 \\
\hline DV565359 & 60S ribosomal protein L34 & 0.99 & 1.55 & 1.49 & 1.30 \\
\hline DV565926 & 16S mitochondrial ribosomal RNA & 1.58 & 1.59 & 1.32 & 0.76 \\
\hline DV565533 & 40S ribosomal protein $\mathrm{S} 14$ & 1.14 & 1.58 & 1.19 & 1.21 \\
\hline DV565731 & 40S ribosomal protein $\mathrm{S} 27$ & 0.99 & 1.52 & 1.34 & 1.16 \\
\hline DV565372 & Protein transport protein SEC61 gamma subunit & 1.05 & 1.59 & 1.05 & 1.05 \\
\hline
\end{tabular}


Table 3. Limanda limanda. Transcripts significantly (FDR < 0.05) repressed at least 1.5 -fold (fold changes in gene expression between tumor and non-tumor) in one or more groups of tumor samples. GenBank: example flounder GenBank accession number; Common name: putative identity of gene. Those samples with FDR $<0.05$ are shown in bold italics; those with single $t$-test p-values $<0.05$ are shown in bold. See Table 2 for abbreviations

\begin{tabular}{|c|c|c|c|c|c|}
\hline GenBank & Common name & F-HA & F-HC & M-HA & $\mathrm{M}-\mathrm{HC}$ \\
\hline DV565619 & Apolipoprotein A-IV & 0.65 & 1.61 & 0.99 & 0.96 \\
\hline DV568183 & Cytochrome b5 & 1.11 & 0.62 & 1.13 & 1.15 \\
\hline DV566197 & Alanine-glyoxylate aminotransferase & 1.06 & 0.60 & 1.39 & 0.81 \\
\hline DV567002 & Similar to onzin & 1.00 & 0.63 & 1.25 & 0.89 \\
\hline DV565297 & C-type lectin 2-1 & 1.19 & 0.66 & 0.89 & 1.01 \\
\hline DV569985 & Actin-related protein $2 / 3$ complex & 0.66 & 1.04 & 1.07 & 0.95 \\
\hline EC378548 & Glyceraldehyde 3-phosphate dehydrogenase & 0.89 & 0.57 & 0.84 & 1.13 \\
\hline DV567117 & Ceruloplasmin precursor (fFerroxidase) & 0.97 & 0.60 & 0.94 & 0.81 \\
\hline DV566228 & Beta-hexosaminidase alpha chain precursor & 0.94 & 0.46 & 1.03 & 0.89 \\
\hline DV565380 & High choriolytic enzyme 1 precursor & 0.76 & 1.00 & 0.51 & 1.03 \\
\hline AJ578044 & Cytochrome c oxidase polypeptide II & 0.96 & 0.50 & 0.99 & 0.84 \\
\hline DV566124 & Cytochrome c oxidase polypeptide III & 0.97 & 0.60 & 0.93 & 0.77 \\
\hline DV567956 & Selenide water dikinase 2 & 1.01 & 0.64 & 0.79 & 0.83 \\
\hline DV565511 & Putative ISG12 protein & 0.91 & 0.72 & 0.98 & 0.63 \\
\hline AJ580013 & Cathepsin L & 0.49 & 0.86 & 0.90 & 0.95 \\
\hline DV567061 & Prothrombin precursor & 1.05 & 0.66 & 0.72 & 0.76 \\
\hline DV565348 & Hepcidin-like precursor & 0.92 & 0.73 & 0.61 & 0.91 \\
\hline DV565688 & Hepcidin precursor & 0.91 & 0.69 & 0.65 & 0.91 \\
\hline DV565968 & Chymotrypsinogen 2 & 0.74 & 1.14 & 0.48 & 0.69 \\
\hline AJ508542 & MHC II invariant chain & 1.22 & 0.40 & 0.73 & 0.69 \\
\hline DV570186 & UDP-glucuronosyltransferase 2A1 & 0.66 & 1.05 & 0.68 & 0.59 \\
\hline AJ310423 & Apolipoprotein AI & 0.80 & 0.51 & 0.79 & 0.83 \\
\hline AJ310418 & Fibrinogen gamma & 0.80 & 0.57 & 0.68 & 0.87 \\
\hline AJ508737 & Fibrinogen alpha & 0.84 & 0.61 & 0.60 & 0.83 \\
\hline DV565399 & Kininogen 1 & 0.82 & 0.55 & 0.65 & 0.82 \\
\hline AJ605266 & Alpha-1-antitrypsin & 0.73 & 0.50 & 0.76 & 0.83 \\
\hline AJ605271 & Cytochrome P450 monooxygenase CYP2K6 & 0.87 & 0.56 & 0.64 & 0.73 \\
\hline DV565529 & Cytochrome c oxidase subunit I & 0.88 & 0.36 & 0.85 & 0.68 \\
\hline DV567824 & NADH dehydrogenase subunit 4 & 0.84 & 0.56 & 0.70 & 0.66 \\
\hline DV565300 & Carboxypeptidase A1 & 0.58 & 0.89 & 0.33 & 0.92 \\
\hline DV566497 & Vacuolar-proton-APTase subunit M9.2 & 0.62 & 0.66 & 0.66 & 0.75 \\
\hline AJ132353 & CYP1A Cytochrome P450 1A & 0.74 & 0.36 & 0.83 & 0.72 \\
\hline AJ508743 & Alpha-2-macroglobulin & 0.62 & 0.55 & 0.65 & 0.79 \\
\hline DV567349 & cDNA clone lithmor74 similar to fFibronectin $1 \mathrm{~b}$ & 0.70 & 0.44 & 0.72 & 0.60 \\
\hline DV565675 & Liver-expressed antimicrobial peptide 2A & 0.65 & 0.61 & 0.59 & 0.58 \\
\hline AJ543346 & Bile salt-activated lipase (BAL) & 0.96 & 0.63 & 0.34 & 0.40 \\
\hline DV567212 & cDNA clone similar to microsomal GST-3 & 0.33 & 0.31 & 0.59 & 0.51 \\
\hline
\end{tabular}

transcripts statistically significantly induced or repressed at least 1.5-fold in one or more comparisons between tumor and non-tumor tissues (see Figs. $2 \& 3$ for heat maps displaying variation within sample groups). Fish ID no. 4 (see Table 1) showed high hybridization to negative controls in the HC tumor sub-sample and was therefore eliminated from further analysis as it was considered to be contaminated. For female HA samples, 107 genes changed by 1.5 -fold or more, and 35 were statistically significant at FDR $<0.05$, for female HC 574 1.5-fold and 77 significant, male HA 199 1.5-fold and 7 significant, male HC 84 1.5-fold and 45 significant; these included unidentified expressed sequence tags (ESTs) not shown in Tables $2 \& 3$.

Of those transcripts analyzed, the expression of vitellogenins $\mathrm{A}$ and $\mathrm{B}$ showed the greatest induction in tumor compared to non-tumor tissue; however, the expression of these genes was highly variable between individuals (see Table 4, Fig. 6), and not statistically significant at FDR of 0.05 . Choriogenin $\mathrm{L}$ and reticulon 1 transcripts, which we have previously found induced in response to estrogen treatment in flounder (Williams et al. 2007) were induced in female HC samples, though again not significantly due to high variability (Table 4). The group of transcripts that showed most statistically significant changes was those encoding several ribosomal proteins, which were generally, but not highly, induced.

Class prediction via principal component analysis allowed us to find a subset of genes the expression of which could be used to classify samples into their respective tumor 'type' (either HA or HC; see Fig. 4). The genes that were most predictive of group membership are shown in Table 5. Similarly, samples could 


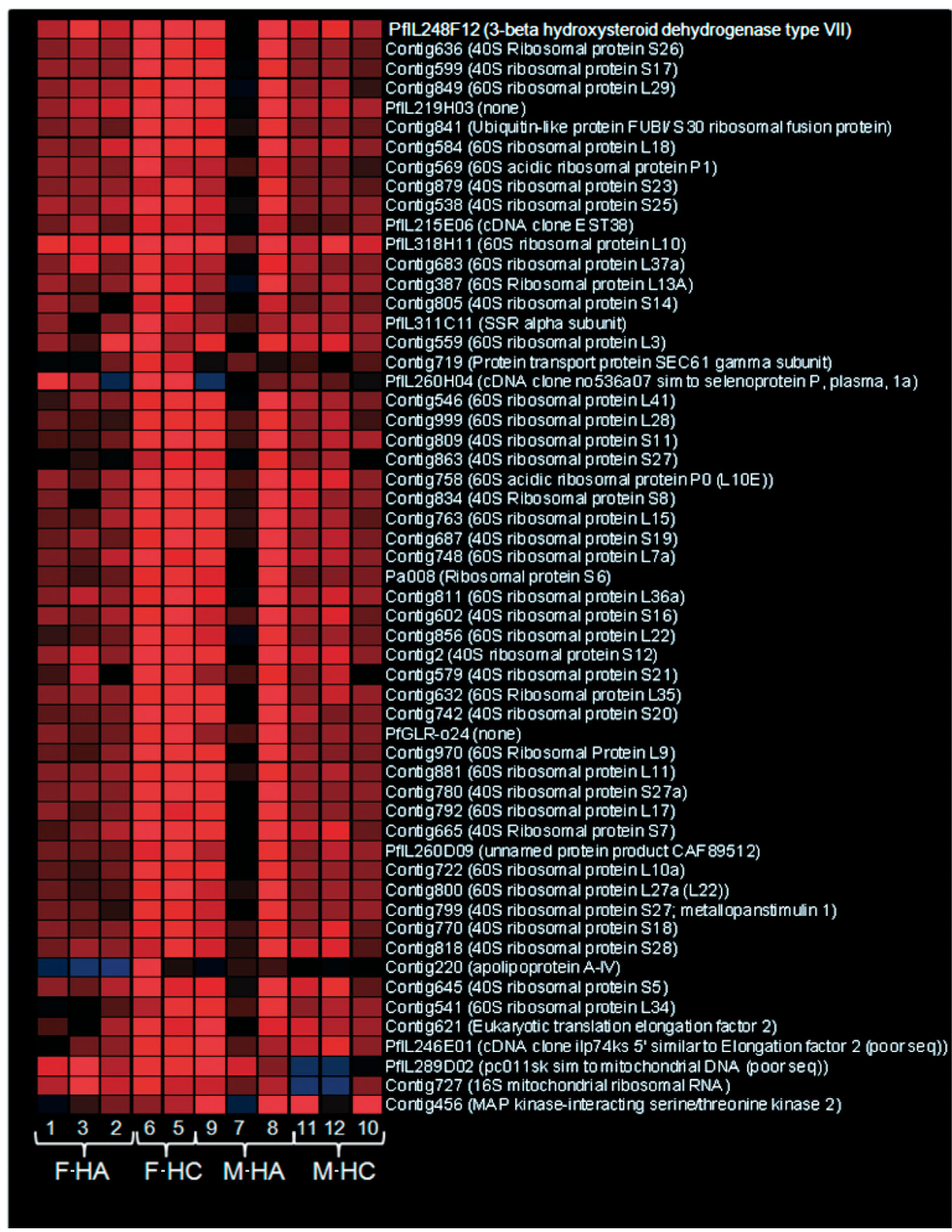

Fig. 2. Limanda limanda. Pattern of transcript expressions from Table 2 (induced at least 1.5-fold; false discovery rate, FDR < 0.05). Red coloration indicates a higher expression in tumor than normal tissue; blue indicates a lower expression in tumour than normal. Intensity of color illustrates fold change with maximum color intensity at 2 -fold change. Unchanging genes are shown as black. 1-12: Fish ID nos., see Table 1; F-HA: female hepatocellular adenoma; F-HC: female hepatocellular carcinoma; M-HA: male hepatocellular adenoma; M-HC: male hepatocellular carcinoma

also be grouped by sex of the host or by both sex and tumor type (data not shown).

Six transcripts, including 3 unidentified ESTs, were found to be significantly influenced (fold changes in gene expression between tumor and non-tumor; FDR < 0.05) by the presence or absence of select secondary pathologies present in the liver tissues surrounding the principal lesion (Table 6). Fish sex, size and sample location had no significant influence on transcript expression.

\section{RT-PCR analysis of mRNA expression}

Melt curve and agarose gel analysis of dab RT-PCR products indicated that, as expected, only a single reaction product was produced using the European 


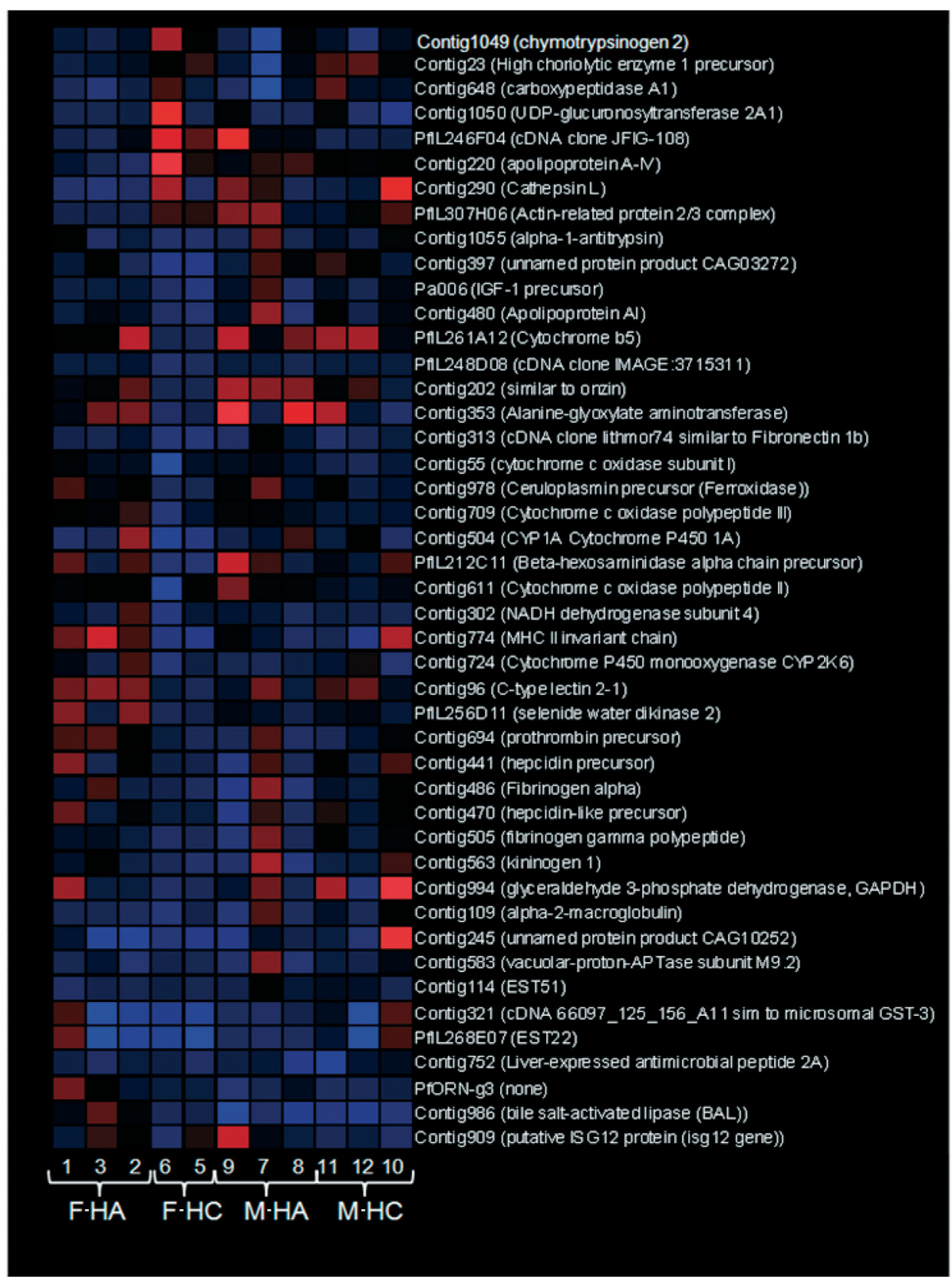

Fig. 3. Limanda limanda. Pattern of transcript expressions from Table 3 (repressed at least 1.5-fold; false discovery rate, FDR < 0.05). See Fig. 2 for explanations and abbreviations

flounder primers for VTG, THX, GST, and ATUB. Sequencing and BLAST analysis of select dab RT-PCR products confirmed that the correct target was amplified (VTG: $98 \%$ similar to $P$. flesus; THX: $94 \%$ similar to P. flesus; GST: $84 \%$ similar to P. flesus; ATUB: $89 \%$ similar to $P$. flesus). Comparison of $C_{t}$ values from ATUB and $18 \mathrm{~S}$ amplifications for HA, HC, and matching normal samples showed that ATUB transcripts were markedly up-regulated in both $\mathrm{HA}$ and $\mathrm{HC}$ tumor samples, compared to matching normal tissues
(Fig. 5). Expression values were therefore normalized using a single reference gene (18S mRNA), a method well accepted in systems lacking a panel of well characterized multiple reference genes (Bustin et al. 2005). RT-PCR results for VTG-B confirmed the microarray findings. There was agreement in the array and RTPCR data, in terms of increased or decreased VTG expression between sample groups (Fig. 6), and in some samples considerable induction of VTG (up to 262 -fold induction when compared to surrounding 
Table 4. Limanda limanda. Transcripts induced or repressed 5-fold or more (fold changes in gene expression between tumor and non-tumor) in one or more groups of tumor samples. GenBank: example flounder GenBank accession number; Common name: putative identity of gene. Those samples with single $t$-test p-values $<0.05$ are shown in bold. See Table 2 for abbreviations

\begin{tabular}{|c|c|c|c|c|c|}
\hline GenBank & Common name & F-HA & $\mathrm{F}-\mathrm{HC}$ & M-HA & $\mathrm{M}-\mathrm{HC}$ \\
\hline DV567998 & Vitellogenin A & 3.43 & 343.32 & 8.73 & 9.57 \\
\hline DV567625 & Vitellogenin A & 3.11 & 208.33 & 6.99 & 7.39 \\
\hline AJ416327 & Vitellogenin B & 5.19 & 187.91 & 7.15 & 3.77 \\
\hline DV565941 & Choriogenin L & 1.30 & 10.32 & 0.96 & 0.88 \\
\hline DV567933 & Reticulon 1 & 1.06 & 6.96 & 0.86 & 1.27 \\
\hline DV568108 & C-type lectin 1 & 1.13 & 0.18 & 1.03 & 0.68 \\
\hline DV568963 & C-type lectin 1 & 1.11 & 0.16 & 0.95 & 0.63 \\
\hline DV565329 & Glutathione S-transferase GST-A & 0.79 & 0.14 & 1.00 & 0.64 \\
\hline X95199 & 3' untranslated region of GST-A & 0.64 & 0.19 & 0.99 & 0.66 \\
\hline
\end{tabular}

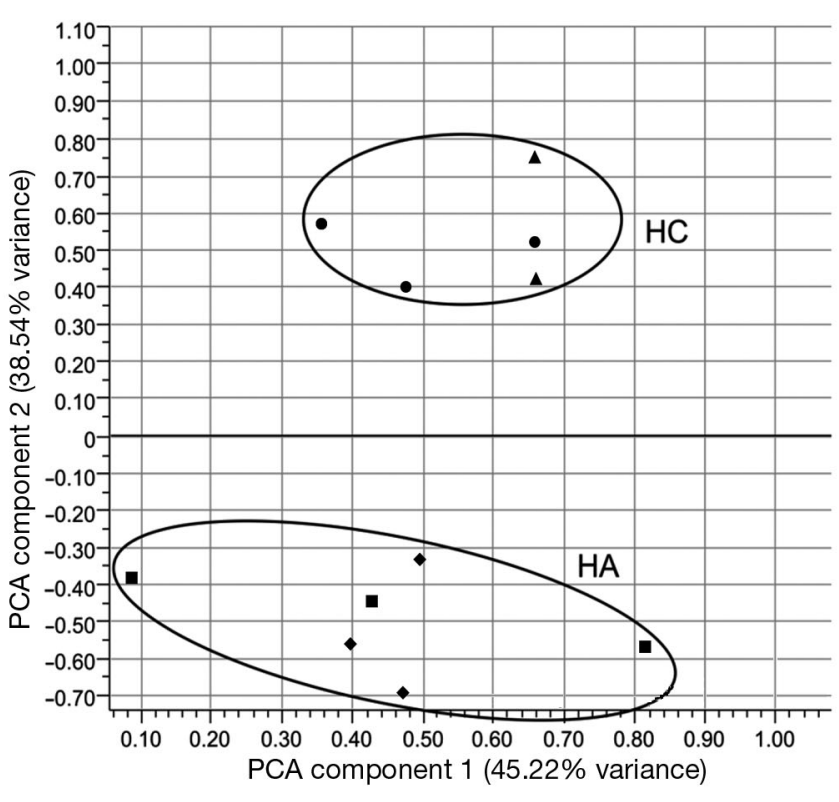

Fig. 4. Limanda limanda. Principal components analysis of the expression of 50 mRNA transcripts best able to predict the tumor type of the hepatocellular carcinoma $\left(\mathrm{HC}_{i} \mathrm{n}=5\right)$ and dab hepatocellular adenoma $\left(\mathrm{HA}_{;} \mathrm{n}=6\right)$ samples (see Fig. 1 for abbreviations). $\mathbf{m}: \mathrm{M}-\mathrm{HA} ; \bullet:$ F-HA: $\bullet: \mathrm{M}-\mathrm{HC} ; \mathbf{\wedge}:$ F-HC

normal hepatic tissue). However, as observed with the array data, there was substantial variation in VTG expression between samples from the same group (sex of host and tumor type). There was a considerable increase in mean VTG expression in 2 out of 3 female HC samples (262- and 50.3-fold increase, tumor vs. normal) and in 2 of the male HA (219.6- and 42.1-fold increase, tumor vs. normal) and HC (71.8- and 6.7-fold increase, tumor vs. normal) samples. Female HA samples showed little induction of VTG (2.6, 2.3 and 2.4). No significant differences were observed between tumor types in either female or male samples for GST or THX (Fig. 7).

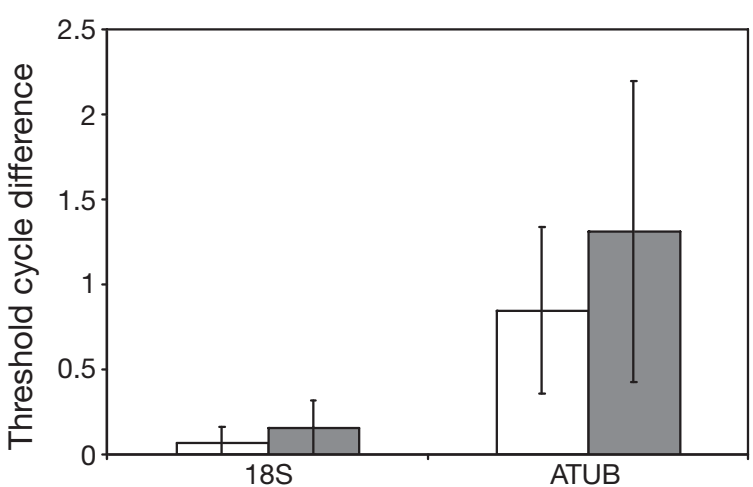

Fig. 5. Limanda limanda. Comparison of threshold cycle $\left(C_{t}\right)$ differences observed between matched normal and tumor samples HA (open columns) and HC (filled columns) for 2 commonly used control genes (18S rRNA and $\alpha$-tubulin, ATUB). The graph shows the mean $C_{t}( \pm \mathrm{SD})$ for each lesion type $(\mathrm{n}=6)$

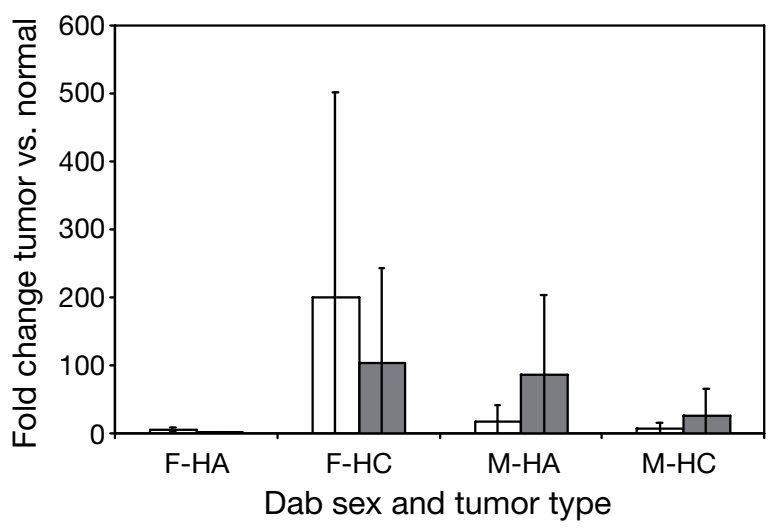

Fig. 6. Limanda limanda. Vitellogenin-B (VTG-B) mRNA expression analysis in female $(\mathrm{F})$ and male $(\mathrm{M})$ dab HA and HC by microarray (open columns) and RT-PCR (filled columns). See Fig. 1 for abbreviations. $n=3$ per group $( \pm S D)$, apart from microarray analysis of F-HC where $n=2$ 
Table 5. Limanda limanda. Transcripts whose expression (fold changes in gene expression between tumor and non-tumor) best predicts class membership when grouped by tumor type, with expression values in each group of samples. GenBank: example flounder GenBank accession number; Common name: putative identity of gene. NA: not available; none: clones with no similarity (at BLAST $E$-value $<1 \times 10^{-6}$ ) to known sequences. See Table 2 for abbreviations

\begin{tabular}{|c|c|c|c|c|c|}
\hline GenBank & Common name & F-HA & F-HC & M-HA & $\mathrm{M}-\mathrm{HC}$ \\
\hline DV569643 & Translocon-associated protein, delta subunit precursor & 0.94 & 1.47 & 0.88 & 1.11 \\
\hline AY156727 & GST alpha & 0.97 & 0.63 & 1.00 & 0.78 \\
\hline DV565765 & Apolipoprotein D precursor & 0.79 & 1.41 & 1.02 & 1.24 \\
\hline DV565318 & Trypsinogen 2 precursor & 0.43 & 0.71 & 0.28 & 0.90 \\
\hline AJ306239 & Complement component $\mathrm{C} 8$ beta chain precursor & 0.93 & 1.18 & 0.69 & 1.26 \\
\hline DV566243 & Isochorismatase domain containing 2 & 1.08 & 0.72 & 0.89 & 0.81 \\
\hline DV565628 & cDNA clone CNB74-B11 & 0.97 & 0.71 & 0.94 & 0.81 \\
\hline DV568443 & $\mathrm{N}(4)$-(beta-N-acetylglucosaminyl)-L-asparaginase precursor & 1.10 & 1.26 & 0.97 & 1.09 \\
\hline DV565380 & High choriolytic enzyme 1 precursor & 0.76 & 1.00 & 0.51 & 1.03 \\
\hline DV566614 & NHP2 non-histone chromosome protein 2-like 1 & 1.16 & 0.87 & 1.43 & 1.07 \\
\hline DV567812 & RNA 3'-terminal phosphate cyclase-like protein & 0.91 & 1.00 & 0.67 & 1.03 \\
\hline DV565825 & $\mathrm{X}$-box binding protein $1 \mathrm{~B}$ & 0.75 & 3.35 & 0.98 & 1.35 \\
\hline DV569697 & $40 \mathrm{~S}$ ribosomal protein $\mathrm{S} 15 \mathrm{~A}$ & 0.96 & 1.69 & 1.17 & 1.44 \\
\hline DV570302 & cDNA clone CGX46-A10 & 0.78 & 1.28 & 0.92 & 1.06 \\
\hline DV565349 & Glutathione peroxidase 1 & 1.08 & 0.92 & 1.51 & 0.78 \\
\hline DV565962 & cDNA clone CR726539 & 1.30 & 0.93 & 1.17 & 0.85 \\
\hline DV568963 & C-type lectin 1 & 1.11 & 0.16 & 0.95 & 0.63 \\
\hline DV565529 & Cytochrome c oxidase subunit I & 0.88 & 0.36 & 0.85 & 0.68 \\
\hline DV565300 & Carboxypeptidase A1 & 0.58 & 0.89 & 0.33 & 0.92 \\
\hline DV566124 & Cytochrome c oxidase polypeptide III & 0.97 & 0.60 & 0.93 & 0.77 \\
\hline DV565583 & High choriolytic enzyme 1 precursor & 0.96 & 1.12 & 0.54 & 1.05 \\
\hline DV568965 & Trypsinogen 2 precursor & 0.53 & 0.84 & 0.28 & 0.99 \\
\hline DV565421 & Trypsin & 0.66 & 0.89 & 0.40 & 0.91 \\
\hline NA & Complement component C4B & 0.79 & 0.95 & 0.66 & 1.07 \\
\hline DV565298 & Reticulon-1 & 0.82 & 3.30 & 0.77 & 1.19 \\
\hline DV565467 & Bromodomain-containing 3 & 1.01 & 0.92 & 1.03 & 0.88 \\
\hline DV565448 & Mitochondrial ATP synthase c-subunit (P3) & 1.25 & 0.88 & 1.12 & 1.00 \\
\hline DV565632 & FAD-synthetase (Pp591) & 1.03 & 1.18 & 1.05 & 1.16 \\
\hline EC377685 & STEAP family member 4 & 0.89 & 0.94 & 0.74 & 0.98 \\
\hline DV565984 & Interleukin-8 variant & 1.07 & 0.74 & 0.93 & 0.89 \\
\hline DV566096 & None & 1.24 & 1.06 & 1.13 & 1.12 \\
\hline DV566112 & cDNA clone JFConA425F & 0.99 & 1.13 & 0.92 & 1.02 \\
\hline DV566160 & Survivin 1 & 1.15 & 0.91 & 1.13 & 0.94 \\
\hline DV566675 & None & 0.67 & 0.97 & 0.65 & 0.99 \\
\hline DV566685 & Tryptophan 2,3-dioxygenase & 1.24 & 1.57 & 0.94 & 1.75 \\
\hline DV567152 & Hypothetical protein zgc:77713 & 1.07 & 1.50 & 0.83 & 1.02 \\
\hline DV567855 & Hypothetical protein Q6PBK5 & 1.07 & 1.18 & 1.02 & 1.19 \\
\hline EC378563 & Intraflagellar transport protein 20 & 0.98 & 1.23 & 0.91 & 1.10 \\
\hline DV568108 & C-type lectin 1 & 1.13 & 0.18 & 1.03 & 0.68 \\
\hline DV568416 & Mitochondrial citrate synthase precursor (CS) & 1.54 & 0.74 & 1.05 & 0.96 \\
\hline EC378950 & Very large inducible GTPase 1 & 0.92 & 1.26 & 0.99 & 1.11 \\
\hline DV568905 & None & 1.15 & 0.73 & 1.03 & 0.85 \\
\hline DV569328 & Rag C (Ras-related GTP binding C) & 1.04 & 0.88 & 0.95 & 0.90 \\
\hline DV569295 & AT rich interactive domain $1 \mathrm{~A}$ & 0.91 & 0.87 & 0.95 & 0.85 \\
\hline EC379169 & Cut-like 1 & 0.97 & 1.22 & 1.03 & 1.20 \\
\hline DV569485 & Leukotriene B4 12-hydroxydehydrogenase & 1.13 & 1.26 & 1.05 & 1.26 \\
\hline EC379219 & RNA binding motif protein 25 & 1.09 & 0.89 & 0.96 & 0.86 \\
\hline DV569644 & Aldose reductase-related protein 2 & 0.86 & 0.70 & 0.85 & 0.70 \\
\hline DV570097 & SSR alpha subunit & 1.14 & 2.28 & 1.24 & 1.35 \\
\hline DV570352 & Hypothetical protein zgc:73259 & 1.24 & 0.87 & 1.31 & 1.12 \\
\hline
\end{tabular}

\section{DISCUSSION}

In this proof-of-concept study, the microarray and RT-PCR data were characterized by high biological variability between samples within the same group (host sex and tumor type), which is not unexpected, as no 2 environmentally induced tumors are expected to have exactly the same etiology, especially as the fish used for the trial were of different lengths and captured from different locations around the UK coastline. Nevertheless, the analyses did indicate that gene expression differences exist between HA and HC from 
Table 6. Limanda limanda. Gene expression differences (alterations at FDR $<0.05$ in fold changes between tumor and non-tumor samples) associated with (-) absence or (+) presence of certain secondary pathologies in the liver tissue surrounding the principal lesion (HA or HC). GenBank: example flounder GenBank accession number; Common name: putative identity of gene; T: tumor; $\mathrm{N}$ : normal; none: clones with no similarity (at BLAST $E$-value $<1 \times 10^{-6}$ ) to known sequences. See Tables $1 \& 2$ for abbreviations

\begin{tabular}{|c|c|c|c|c|}
\hline \multirow{2}{*}{$\begin{array}{l}\text { Secondary lesion/ } \\
\text { pathology }\end{array}$} & \multirow{2}{*}{ GenBank } & \multirow{2}{*}{ Common name } & \multicolumn{2}{|c|}{ Mean expression } \\
\hline & & & $\begin{array}{l}\text { T/N without } \\
\text { pathology }(-)\end{array}$ & $\begin{array}{c}\text { T/N with } \\
\text { pathology (+) }\end{array}$ \\
\hline $\mathrm{CN}$ & DV570132 & None & 0.893 & 1.304 \\
\hline \multirow[t]{4}{*}{ vFCA } & EC378836 & Small nuclear RNA activating complex, polypeptide 3 & 1.093 & 1.303 \\
\hline & EC378277 & Cross-immune reaction antigen PCIA1 & 0.972 & 1.232 \\
\hline & DV567954 & RNA polymerase I polypeptide D & 1.048 & 1.627 \\
\hline & EC378552 & Unnamed protein product CAG00637 & 1.028 & 1.275 \\
\hline \multirow[t]{2}{*}{ bFCA } & DV567398 & cDNA clone CLJ77-B05 & 1.077 & 0.793 \\
\hline & DV568855 & None & 1.003 & 0.636 \\
\hline
\end{tabular}

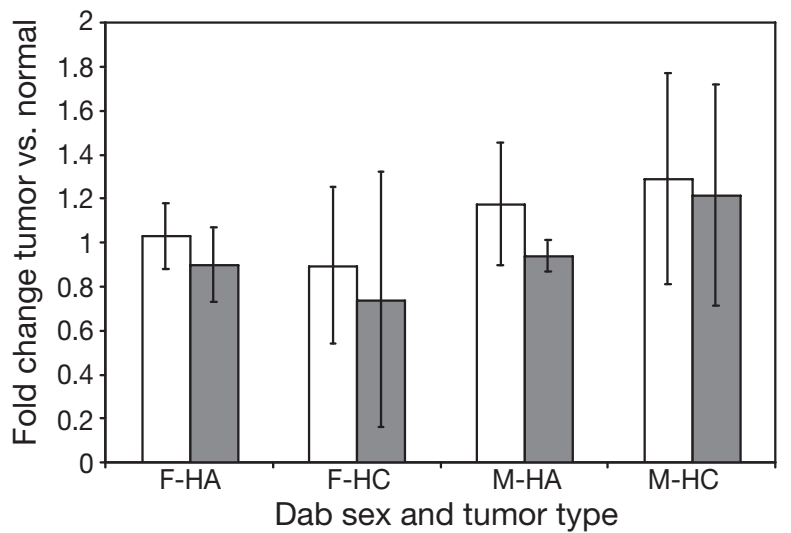

Fig. 7. Limanda limanda. Glutathione-S-transferase (GST; open columns) and thioredoxin (THX; filled columns) mRNA expression analysis in female (F) and male (M) dab HA and HC by RT-PCR. See Fig. 1 for abbreviations. $n=3$ per group $( \pm \mathrm{SD})$

both female and male dab, and, conversely, that the tumors were correctly classified according to histopathological diagnostic criteria. As such, the data may begin to unearth clues as to the environmental pressures driving flatfish tumor progression. Understanding such drivers is essential when using fish disease as a prognostic marker to environmental health (Thain et al. 2008, Stentiford et al. 2009). In addition, the present study highlighted candidate mRNA transcripts for further study (see Table 5), such as VTG, choriogenin L, and reticulon 1, whose association with tumors of wild fish has, to the best of our knowledge, not been previously documented.

The class prediction approach using the cDNA array results indicated that within this particular data set there were sufficient group-specific transcript expression profiles to allow segregation of samples dependent on their tumor type (see Table 5). The differences between benign (HA) and malignant (HC) liver tumor expression profiles are likely due to differences in their growth and invasive properties. Recent studies assessing retinoblastoma allele status in tumors ( $\mathrm{HC}$ and $\mathrm{HA}$ ) and normal liver tissues of dab sampled from similar geographical locations as the present study have also indicated that it is possible to use genetic information to predict sample phenotype (Rotchell et al. 2009). Due to the relatively low replicate numbers $(n=5,6)$ and high inter-individual variability, the specific groups of 'predictive genes' will require further testing with an increased number of additional samples to fully validate these transcriptional signatures. Future studies may also include an analysis of whether the numbers of predictive genes can be reduced, or whether early non-neoplastic lesions such as foci of cellular alteration, which are considered early stage indicators of tumor formation in flatfish (Kohler et al. 1992), display similar transcriptional profiles to those of HA or HC. Nonetheless, our study implies that mRNA expression profiles are of utility in determining and delineating between hepatic tumors in dab, and potentially other cancers of fish.

Six transcripts were found to be significantly influenced by the presence or absence of select secondary pathologies present in the liver tissues surrounding the principal lesion (see Tables 1 \& 6). It would appear that in the presence of either coagulative necrosis or a vacuolated focus of cellular alteration 5 transcripts are induced, while the presence of a basophilic focus of cellular alteration results in a repression of 2 transcripts. However, the 'non-tumor' materials were sampled from the tissues surrounding the principal lesion and may have contained secondary lesions, thus influencing the results. In addition, other factors, pathologies and parasites not present in the original tissues section, but present in the remaining liver tissues, may also have influenced gene expression prior to sample resection.

The array data indicated that there was high statistical confidence in induction (though to a modest extent) 
of several ribosomal proteins in tissues of both tumor types. This is not unexpected, since induction of the protein synthetic apparatus would be required in proliferating cells within tumors. Nonetheless, we were able to show that normalization of RT-PCR data to $18 \mathrm{~S}$ mRNA rather than ATUB (the only 2 reference genes used in prior flatfish RT-PCR studies) was appropriate, and gave comparable data to the array results, albeit with some variation (discussed below). Other orthologous genes significantly changing in expression and known to be involved in carcinogenesis included cathepsin L, 3ß-hydroxysteroid dehydrogenase type VII, and a cDNA clone similar to selenoprotein P. Cathepsin L is a protease that is believed to be secreted by cancerous cells to facilitate tumor invasion and metastasis by degrading the components of the extracellular matrix. It has been documented to be up-regulated in a range of human cancers (Chauhan et al. 1991) and in HC in rainbow trout (Tilton et al. 2005). In humans, the closely related $17 \beta$-hydroxysteroid dehydrogenase is responsible for sex steroid metabolism (conversion of active estradiol to the less potent estrone) in normal and tumor tissues. It has been found to be up-regulated in breast tumors (Oduwole et al. 2004) and, conversely, has also been found to be reduced in colonic tumors (English et al. 1999). The apparent increase in expression of $3 \beta$-hydroxysteroid dehydrogenase in $\mathrm{HC}$ from female fish may indicate estrogen exposure and subsequent estrogen inactivation, and may be an important mechanism in the pathogenesis of HC. Selenoprotein P is known to bind selenium and protect against oxidative stress, and has previously been found to be down-regulated in murine and human tumors (Calvo et al. 2002); however, in our studies a transcript similar to this was moderately upregulated in $\mathrm{HC}$ from female fish and may have a different function in hepatic tumors in dab.

VTG is a large serum glyco-lipo-protein and serves as the major precursor to the egg yolk proteins of oviparous vertebrates. It is synthesized and secreted by the liver, and is normally undetectable in the plasma of immature females and male fish. Classically, VTG has been measured as a biomarker for estrogen exposure (Christiansen et al. 1998, Denslow et al. 2001, Larkin et al. 2003), and elevated levels have recently been documented in flounder populations from some estuaries (Kleinkauf et al. 2004) and in dab from offshore sites (Scott et al. 2007), indicating that these fish may well suffer from endocrine disruption. Further support for this hypothesis comes from Stentiford \& Feist (2005), who reported intersex (ovotestis) in dab from the North Sea, and suggest that these fish may be exposed to endocrine-disrupting chemicals. In addition, elevated levels of VTG have also been recorded in the serum from brown bullhead Ameiurus nebulo- sus with liver tumors (HA and $\mathrm{HC}$ ) collected from a contaminated industrial site (Heppell et al. 1995). Interestingly, Tilton et al. (2005) observed that VTG transcription was not elevated in aflatoxin $\mathrm{B}_{1}$-induced liver $\mathrm{HC}$ from rainbow trout. However, in a subsequent study investigating the effects of $17 \beta$-estradiol upon gene expression in aflatoxin $\mathrm{B}_{1}$-induced liver $\mathrm{HCs}$, they recorded substantial up-regulation of VTG transcripts (Tilton et al. 2007). In addition, several other genes that have previously been found in response to estrogen treatment of flounder (Williams et al. 2007) were also up-regulated in female dab with HC. These included choriogenin L (a precursor protein of the egg envelope) and reticulons (a group of integral membrane proteins that are implicated in cellular processes including apoptosis and axonal regeneration). In combination with VTG induction (above), these transcriptional responses indicate that hepatocarcinogenesis of wild dab is influenced through estrogenic mechanisms, as has been suggested for hepatocarcinogenesis of flounder inhabiting Dutch and German waters (Vethaak \& Jol 1996, Köhler 2004, Vethaak et al. 2009). Whether anthropogenic (exogenous) endocrinedisrupting sources can contribute to the high prevalence of liver tumors observed in European flatfish warrants further study, particularly since the highest tumor prevalence in dab observed at offshore sites around the UK (e.g. Dogger Bank) coincides with those sites where intersex and elevated VTG expression have previously been reported (Stentiford \& Feist 2005, Scott et al. 2007, Stentiford et al. 2009).

Differences observed between the array and RTPCR data (such as the VTG results) are most likely explained by the simple fact that RT-PCR is more sensitive than the microarray, especially with regard to quantification of low-level transcripts (such as VTG in male fish). Other contributing factors may include our use of separate RNA preparations (from the same tumor and normal liver samples) for the array and RTPCR analysis. The possibility therefore exists that RNA extracted from different subpopulations of the same tumor sample had different expression profiles. Several studies investigating human melanoma and breast cancer cell populations have reported heterogeneity of genetic alterations and gene expression in different regions from the same tumors (Wild et al. 2000, Goidin et al. 2001, Zhu et al. 2003), and it is reasonable to assume that different portions of hepatic tumors contain dissimilar expression profiles, such as at the periphery of an invasive tumor versus the centre of the same lesion. Alternatively, as 2 different methods were used in the reverse transcription step (the array used Oligo(dT), whereas the QuantiTect Reverse Transcription Kit used a mixture of Oligo(dT) and random primers), this may have influenced the 
efficiency of priming, leading to an imbalance of certain transcripts.

The differences observed in VTG expression between samples from the same tumor groups are probably due to the use of fish sampled from different locations. Although sample sizes were small, it is worth noting that the HA from female dab sampled from the same geographical location (West Dogger; see Table 1) had the smallest within-group expression and variation in VTG induction, when compared to the other sample groups (F-HC, M-HA, M-HC) from dab captured from different locations. This may suggest that geographical location of capture (and therefore potential exposure to carcinogens and/or promoters, or differences in the genetics of the host) may be important factors for tumor initiation and progression, and the resulting transcriptional profiles obtained in this study, and warrants further study. This hypothesis is supported by the recent demonstration that not only are disease profiles in dab distinctive between geographic locations, but also that these patterns are maintained over time, suggesting some biological basis to the pattern (Stentiford et al. 2009). Alternatively, exposure to potential carcinogens and/or promoters may occur while juvenile dab inhabit coastal waters until they reach $2+$ yr when they may move offshore to join adult populations (Henderson 1998). Recently developed microsatellite markers for dab will undoubtedly add to our understanding of the underlying genetic differences between geographically isolated populations (Tysklind et al. 2009).

VTG transcripts detected in female European flounder have previously been shown to vary widely between individuals (Williams et al. 2003). Ward et al. (2006) also reported considerable variation in plasma proteomic features in dab with $\mathrm{HC}$ when compared to dab with HA tumors. In addition, these authors noted significant differences in the plasma proteome in dab from different geographical locations (the North and Irish Seas). Likewise, Stentiford et al. (2005) reported that unsupervised analysis of proteomic and metabolomic profiles from dab liver tumors and normal tissues indicated that fish-to-fish variability exceeded the differences between non-tumor and tumor samples from the same fish. Using supervised analysis (using partial least-squares regression) the authors were able to separate both the proteomic and metabolomic non-tumor and tumor datasets; however, even in this large dataset, fish tumors showing atypical proteomic and metabolomic profiles were still identified. This finding is in agreement with the present study, in which certain tumor samples showed substantially different expression profiles compared to other tumors (see fish ID no. 7, Figs. 2 \& 3). All of these features strongly support the need for co-collec- tion of important life history data when attempting to decipher cause-and-effect relationships in onset of disease in wild aquatic animal populations (Hines et al. 2007, Bignell et al. 2008, Stentiford et al. 2009).

Other possible explanations for the within-group variation include use of tumor samples that may have been resected from different parts of nodules expressing different transcriptional profiles (as discussed above). Laser Micro-Dissection (LMD) has the potential to address these issues and to allow researchers to harvest pure populations of cells for genetic analysis. Originally developed by Emmert-Buck et al. (1996) for the analysis of tumor cells, the technique is now used extensively in the many fields of cancer biology (Maitra et al. 2001, Stoehr et al. 2003, Player et al. 2004) and has recently been applied to the investigation of parasitic disease in aquatic species (Small et al. 2008). Future studies in our laboratory are being directed at using LMD coupled with downstream molecular techniques to analyze gene expression in specific tumors and pre-neoplastic lesions such as foci of cellular alteration (FCA) in liver sections exhibiting no gross lesion pathologies. We predict that such an approach will lead to a greater understanding of the etiology of liver tumors in marine sentinel flatfish, and that these improvements will be required to justify the continued usage of marine flatfish as sentinels for marine pollution monitoring.

Acknowledgements. H.J.S. and T.D.W. contributed equally to this work. We thank the crew of the RV 'Cefas Endeavour' for their assistance with sample collection. We thank Lina Gunnarsson for assistance with RNA quality assessment. This work was supported under Cefas contract DP195 (to G.D.S.).

\section{LITERATURE CITED}

Altschul SF, Gish W, Miller W, Myers EW, Lipman DJ (1990) Basic local alignment search tool. J Mol Biol 215:403-410

Anonymous (2004) UK National Marine Monitoring Programme, 2nd report (1999-2001). Marine Environment Monitoring Group, Centre for Environment, Fisheries and Aquaculture Science (Cefas), Weymouth

Bailey GS, Williams DE, Hendricks JD (1996) Fish models for environmental carcinogenesis: the rainbow trout. Environ Health Perspect 104:5-21

Benjamini Y, Hochberg Y (1995) Controlling the false discovery rate: a practical and powerful approach to multiple testing. J R Stat Soc B 57:289-300

Bignell JP, Dodge MJ, Feist SW, Lyons B and others (2008) Mussel histopathology: effects of season, disease and species. Aquat Biol 2:1-15

Bucke D, Vethaak AD, Lang T, Mellergaard S (1996) Common diseases and parasites of fish in the North Atlantic: training guide for identification. ICES Techniques in Marine Environmental Sciences, Vol 19. International Council for the Exploration of the Sea (ICES), Copenhagen

- Bustin SA, Benes V, Nolan T, Pfaffl MW (2005) Quantitative real time RT-PCR - a perspective. J Mol Endocrinol 34: 
$597-601$

Calvo A, Xiao N, Kang J, Best CJ and others (2002) Alterations in gene expression profiles during prostate cancer progression: functional correlations to tumorigenicity and down-regulation of selenoprotein-P in mouse and human tumors. Cancer Res 62:5325-5335

> Chauhan SS, Goldstein LJ, Gottesman MM (1991) Expression of cathepsin L in human tumors. Cancer Res 51: $1478-1481$

Christiansen LB, Pedersen KL, Korsgaard B, Bjerregaard P (1998) Estrogenicity of xenobiotics in rainbow trout (Oncorhyncus mykiss) using in vivo synthesis of vitellogenin as a biomarker. Mar Environ Res 46:137-140

> Cohen R, Chalifa-Caspi V, Williams TD, Auslander M, George SG, Chipman JK, Tom M (2007) Estimating the efficiency of fish cross-species cDNA microarray hybridization. Mar Biotechnol 9:491-499

Denslow ND, Lee HS, Bowman CJ, Hemmer MJ, Folmar LC (2001) Multiple responses in gene expression in fish treated with estrogen. Comp Biochem Physiol B 129: 277-282

> Diab AM, Williams TD, Sabine VS, Chipman JK, George SG (2008) The GENIPOL European flounder Platichthys flesus L. toxicogenomics microarray: application for investigation of the response to furunculosis vaccination. J Fish Biol 72:2154-2169

Douglas SE (2006) Microarray studies of gene expression in fish. OMICS 10:474-489

du Corbier FA, Stentiford GD, Lyons BP, Rotchell JM (2005) Isolation of the Retinoblastoma cDNA from the marine flatfish Dab (Limanda limanda) and evidence of mutational alterations in liver tumors. Environ Sci Technol 39: 9785-9790

Emmert-Buck MR, Bonner RF, Smith PD, Chuaqui RF and others (1996) Laser capture microdissection. Science 274: 998-1001

English MA, Kane KF, Cruickshank N, Langman MJS, Stewart PM, Hewison M (1999) Loss of estrogen inactivation in colonic cancer. J Clin Endocrinol Metab 84:2080-2085

Feist SW, Lang T, Stentiford GD, Köhler A (2004) Use of liver pathology of the European flatfish dab (Limanda limanda L.) and flounder (Platichthys flesus L.) for monitoring. ICES Tech Mar Environ Sci 38:1-42

Fox CJ, Dickey-Collas M, Winpenny AJ (1997) Spring plankton surveys of the Irish Sea in 1995: the distribution of fish eggs and larvae. Cefas Science Ser Tech Rep 104

> Goidin D, Mamessier A, Staquet MJ, Schmitt D, BerthierVergnes O (2001) Ribosomal 18S RNA prevails over glyceraldehyde-3-phosphate dehydogenase and beta-actin genes as internal standard for quantitative comparison of mRNA levels in invasive and noninvasive human melanoma cell populations. Anal Biochem 295:17-21

> Golub TR, Slonim DK, Tamayo P, Huard C and others (1999) Molecular classification of cancer: class discovery and class prediction by gene expression monitoring. Science 286:531-537

> Henderson PA (1998) On the variation in dab Limanda limanda recruitment: a zoogeographic study. J Sea Res 40:131-142

Heppell SA, Denslow ND, Folmar LC, Sullivan CV (1995) Universal assay for vitellogenin as a biomarker for environmental estrogens. Environ Health Perspect 103:9-15

Hines A, Oladirana GS, Bignell JP, Stentiford GD, Viant MR (2007) Direct sampling of organisms from the field and knowledge of their phenotype: key recommendations for environmental metabolomics. Environ Sci Technol 41: 3375-3381
Kleinkauf A, Scott AP, Stewart C, Simpson MG, Leah RT (2004) Abnormally elevated VTG concentrations in flounder (Platichthys flesus) from the Mersey Estuary (UK): a continuing problem. Ecotoxicol Environ Saf 58:356-364

Köhler A (2004) The gender-specific risks to liver toxicity and cancer of flounder (Platichthys flesus $(L)$.$) at the German$ Wadden Sea coast. Aquat Toxicol 70:257-276

Köhler A, Deisemann H, Lauritzen B (1992) Histological and cytochemical indices of toxic injury in the liver of dab Limanda limanda L. Mar Ecol Prog Ser 91:141-153

Lang T (2002) Fish disease surveys in environmental monitoring: the role of ICES. ICES Mar Sci Symp 215:202-212

Larkin P, Folmar LC, Hemmer MJ, Poston AJ, Denslow ND (2003) Expression profiling of estogenic compounds using sheepshead minnow cDNA macroarray. Environ Health Perspect 111:839-846

Livak KJ, Schmittgen TD (2001) Analysis of relative gene expression data using real-time quantitative PCR and the 2(-Delta Delta C(T)) Method. Methods 25:402-408

Lyons BP, Stentiford GD, Green M, Bignell JP and others (2004) DNA adduct analysis and histopathological biomarkers in European flounder (Platichthys flesus) sampled from UK estuaries. Mutat Res 552:177-186

Maitra A, Wistuba II, Gazdar AF (2001) Microdissection and the study of cancer pathways. Curr Mol Med 1:153-162

Myers MS, Landahl JT, Krahn MM, Johnson LL, McCain BB (1990) Overview of studies on liver carcinogenesis in English sole from Puget Sound: evidence for a xenobiotic chemical aetiology. I. Pathology and epizootiology. Sci Total Environ 94:33-50

> Oduwole OO, Li Y, Isomaa VV, Mäntyniemi A, Pulkka AE, Soini Y, Vihko PT (2004) 17ß-hydroxysteroid dehydrogenase type 1 is an independent prognostic marker in breast cancer. Cancer Res 64:7604-7609

Osuna-Jiménez I, Williams TD, Prieto-Álamo MJ, Abril N, Chipman JK, Puevo C (2009) Immune- and stress-related transcriptomic responses of Solea senegalensis stimulated with lipopolysaccharide and copper sulphate using heterologous cDNA microarrays. Fish Shellfish Immunol 26:699-706

> Player A, Barrett JC, Kawasaki ES (2004) Laser capture microdissection, microarrays and the precise definition of a cancer cell. Expert Rev Mol Diagn 4:831-840

Rhodes DR, Yu J, Shanker K, Deshpande N and others (2004) Large-scale meta-analysis of cancer microarray data identifies common transcriptional profiles of neoplastic transformation and progression. Proc Natl Acad Sci USA 101:9309-9314

Rijnsdorp AD, Vethaak AD, van Leeuwen PI (1992) Population biology of dab Limanda limanda in the southeastern North Sea. Mar Ecol Prog Ser 91:19-35

Rotchell JM, du Corbier FA, Stentiford GD, Lyons BP, Liddle AR, Ostrander GK (2009) A novel population health approach: using fish Retinoblastoma gene profiles as a surrogate for humans. Comp Biochem Physiol C 149: $134-140$

Scott AP, Sanders M, Stentiford GD, Reese RA, Katsiadaki I (2007) Evidence for estrogenic endocrine disruption in an offshore flatfish, the dab (Limanda limanda L.). Mar Environ Res 64:128-148

Sheader DL, Gensberg K, Lyons BP, Chipman JK (2006) Oxidative stress response of European flounder (Platichthys flesus) to cadmium determined by a custom cDNA microarray. Mar Environ Res 62:33-44

Small HJ, Sturve J, Bignell JP, Longshaw M and others (2008) Laser-assisted microdissection: a new tool for aquatic molecular parasitology. Dis Aquat Org 82:151-156 
Stentiford GD, Feist SW (2005) First reported cases of intersex (ovotestis) in the flatfish species dab Limanda limanda: Dogger Bank, North Sea. Mar Ecol Prog Ser 301:307-310

Stentiford GD, Viant MR, Ward DG, Johnson PJ and others (2005) Liver tumors in wild flatfish: a histopathological, proteomic, and metabolomic study. OMICS 9:281-299

Stentiford GD, Bignell JP, Lyons BP, Feist SW (2009) Site-specific disease profiles in fish and their use in environmental monitoring. Mar Ecol Prog Ser 381:1-15

Stern HM, Zon LI (2003) Cancer genetic and drug discovery in the zebrafish. Nat Rev Cancer 3:533-539

Stoehr R, Wild P, Hartmann A (2003) Lasermicrodissection: an important prerequisite for the molecular-genetic analysis of bladder cancer. Pathol Res Pract 199:355-362

Thain JE, Vethaak AD, Hylland K (2008) Contaminants in marine ecosystems: developing an integrated indicator framework using biological effects techniques. ICES J Mar Sci 65:1508-1514

Tilton SC, Gerwick LG, Hendricks JD, Rosato CS and others (2005) Use of a rainbow trout oligonucleotide microarray to determine transcriptional patterns in Aflatoxin $\mathrm{B}_{1}$ induced hepatocellular carcinoma compared to adjacent liver. Toxicol Sci 88:319-330

Tilton SC, Hendricks JD, Orner GA, Pereira CB, Bailey GS, Williams DE (2007) Gene expression analysis during tumor enhancement by the dietary phytochemical, 3, 3-diindolylmethane, in rainbow trout. Carcinogenesis 28: 1589-1598

Tysklind N, Taylor MI, Lyons BP, McCarthy ID, Carvalho GR (2009) Development of 30 microsatellite markers for dab (Limanda limanda L.): a key UK marine biomonitoring species. Mol Ecol Resour 9(3):951-955

Vethaak AD, Jol JG (1996) Diseases of flounder Platichthys flesus in Dutch coastal and estuarine waters, with particular reference to environmental stress factors. I. Epizootiology of gross lesions. Dis Aquat Org 26:81-97

Editorial responsibility: Thomas Lang, Cuxhaven, Germany
Vethaak AD, Wester PW (1996) Diseases of flounder Platichthys flesus in Dutch coastal and estuarine waters, with particular reference to environmental stress factors. II. Liver histopathology. Dis Aquat Org 26:99-116

- Vethaak AD, Jol JG, Pieters JPF (2009) Long-term trends in the prevalence of cancer and other major diseases among flatfish in the southeastern North Sea as indicators of changing ecosystem health. Environ Sci Technol 43: 2151-2158

Ward DG, Wei W, Cheng Y, Billingham LJ and others (2006) Plasma proteome analysis reveals the geographical origin and liver tumor status of dab (Limanda limanda) from UK marine waters. Environ Sci Technol 40:4031-4036

> Wild P, Knuechel R, Dietmaier W, Hofstaedter F, Hartmann A (2000) Laser microdissection and microsatellite analyses of breast cancer reveal a high degree of tumor heterogeneity. Pathobiology 68:180-190

> Williams TD, Gensberg K, Minchin SD, Chipman JK (2003) A DNA expression array to detect toxic stress response in European flounder (Platichthys flesus). Aquat Toxicol 65:141-157

Williams TD, Diab AM, George SG, Godfrey RE and others (2006) Development of the GENIPOL European flounder (Platichthys flesus) microarray and determination of temporal transcriptional responses to cadmium at low dose. Environ Sci Technol 40:6479-6488

> Williams TD, Diab AM, George SG, Sabine V, Chipman JK (2007) Gene expression responses of European flounder (Platichthys flesus) to 17-beta estradiol. Toxicol Lett 168: 236-248

> Zhu G, Reynolds L, Crnogorac-Jurcevic T, Gillett CE and others (2003) Combination of microdissection and microarray analysis to identify gene expression changes between differentially located tumor cells in breast cancer. Oncogene 22:3742-3748

Submitted: April 29, 2009; Accepted: September 2, 2009 Proofs received from author(s): January 11, 2010 